\begin{tabular}{|l|l|l||}
\hline \multicolumn{2}{|c|}{ PublisherInfo } \\
\hline \hline PublisherName & $:$ & BioMed Central \\
\hline \hline PublisherLocation & $:$ & London \\
\hline \hline PublisherImprintName & $:$ & BioMed Central \\
\hline \hline
\end{tabular}

\title{
DNase II and erythropoiesis
}

\begin{tabular}{|l|l|l||}
\hline \multicolumn{2}{|c|}{ ArticleInfo } \\
\hline \hline ArticleID & $:$ & 4100 \\
\hline \hline ArticleDOI & $:$ & $10.1186 /$ gb-spotlight-20010529-01 \\
\hline \hline ArticleCitationID & $:$ & spotlight-20010529-01 \\
\hline \hline ArticleSequenceNumber & $:$ & 171 \\
\hline \hline ArticleCategory & $:$ & Research news \\
\hline \hline ArticleFirstPage & $:$ & 1 \\
\hline \hline ArticleLastPage & $:$ & 2 \\
\hline \hline & & RegistrationDate : 2001-05-29 \\
ArticleHistory & $:$ & OnlineDate \\
\hline \hline ArticleCopyright & $:$ & BioMed Central Ltd2001-05-29 \\
\hline \hline ArticleGrants & $:$ & \\
\hline \hline ArticleContext & $:$ & 130592211 \\
\hline \hline
\end{tabular}


Deoxyribonuclease II (DNase II) is a lysosomal DNase that has been implicated in the degradation of DNA in apoptotic cells. In the May 25 Science, Kawane et al. report the analysis of mice lacking a functional DNase II protein (Science 2001, 292:1546-1549). No DNase II-null mice survived until birth. Mutant embryos developed anemia at embryonic days 12.4-14.5 and had dramatically reduced numbers of mature erythrocytes. Transplantation of DNase II-null fetal liver cells into irradiated mice generated normal erythrocytes, however, indicating that the phenotype is not cell autonomous. Abnormal foci were observed in the livers of mutant embryos, and these contained macrophages with undigested DNA. Thus, DNase II in macrophage lysosomes in the liver is important for digesting nuclear DNA from erythroid precursors and is essential for definitive erythropoiesis.

\section{References}

1. Molecular cloning of the cDNA encoding human deoxyribonuclease II.

2. Science, [http://www.sciencemag.org] 